\title{
Recent destructive earthquakes in the Central Alborz (Iran)
}

\author{
J. S. TChalexiso $(*)$ \\ Received on January 21st, 1973
}

\begin{abstract}
SUMmart. -... Macroseisutic data based on field work and biblio. graphical research is given for six little-known destructive earthrpuakes which ocenred in the Central Alborz, Iran, during the 20th Century. They are: Ah-SIobarakabad 1930, Alborz 1935, Garmsar 1945, Musha 1955, Sangechal 1957 and Babol-Kenar 1971. The locations of the two largest of these earthquakes (1935, and 1957) were fortunately at some listance from the densely populated regions of Tehran and the coastal towns of the Caspian Sea.
\end{abstract}

Riassunto. - Sono stati raceolti lati maerosismici, mediante ricerehe in loco e bilbliografiche, relativi a sei terremoti distruttivi poco conoseinti che sono arvenuti nel $\mathrm{XX}$ secolo nella regione dell:Alhorz centrale (Irau). Iocaliti el anni sono i seguenti: Alh-Mobarakabad, 1930; Alborz, 1935; Garmstrr, 1945; Musha, 1955; Sangechal, 1957; Babol-Kenar, 1971. I più forti di questi teremoli (1935 1957) avvennero fortunatautente and una eerta distanza dalle zone più densamente popolate di Teheran e delle cittì costiere del Mrar Caspio.

\section{1. - INtroduction}

The study of the seismicity of the Central Alborz mountains in Iran is of particular importance because the region is bordered by two of the most populated areas of the country, i.e. the Teluran aggiomeration in the south, and the coastal towns of the Caspian Sea in

(*) Engineering Seismology. Imperial College, Loudon sw7. 
the north. Yet, the to a lack of reliable published macroseismic data, very little is known of these events, even of the more recent destructive ones which took place less than two lecades ago. After about 1960, instrumental determinations of extliquakes bave increased in accurncy, and new microseismic techniques are being applied to the study of the seismicity of the Middle Fast $(12,13,16,17)$, but the uncertitude in epicentral, depth and manitule determinations for Iran, especially for the earlier periork, makes it increasingly important to aequire accurate macroseismic information, at least for the larger lestructive events.

The present note collates the information available on 6 destructive earthquakes which occured this century in the Central Alborz region of North-central Iran. It is not an exhanstive compilation, as more clata will no loubt be obtained from a systematic study of the Persian press and literature, and from further lield investigations. It is hopel however that this note may constitute a starting point for future research on the problem.

\section{2. - SOURCES CONSULTED}

Most of the existing macroseismic data on the earthquakes deseribed here is contained in earthquake catalogues $(18,20,23,27)$ which were usually found to be too general for the present study. Further information was obtained from various published and unpublished reports, from Persian and euopean press reports, and from interviews of survivors conducted by the author in 1971 with the help of H. Tranmanesh and $A$. Molajer- $A$ shjad. The main sources used in adrlition to the earthquake catalogues are as follows: 7930 earthquake, Field Fission (1971) and Etela'at (3 Oct. 1930); 1935 earthquahes, Field Mission (1971), British Embassy reports and Etela'at (20 $\mathrm{\Lambda}$ ]ril 1935); 1945 earthqualie, Bozorgnia (5) and Etela'at (12 May 1945); $195 j$ earthquake, Fichl Mission (1971), Bozorgnia (') and Etela'at (25 Nov. $1955)$; 7957 earthquake, Vrolyk $\left({ }^{26}\right)$, Savage (21) and Ficll Mission (1971); 1971 carthquake, Telaalenko, Tranmanesh and Hohajer-Aslijai (24).

The instrumentally determined parameters of the earthquakes are given in Table 1 and the locations and areas covered by the large seale maps are shown in Fig. 1. 


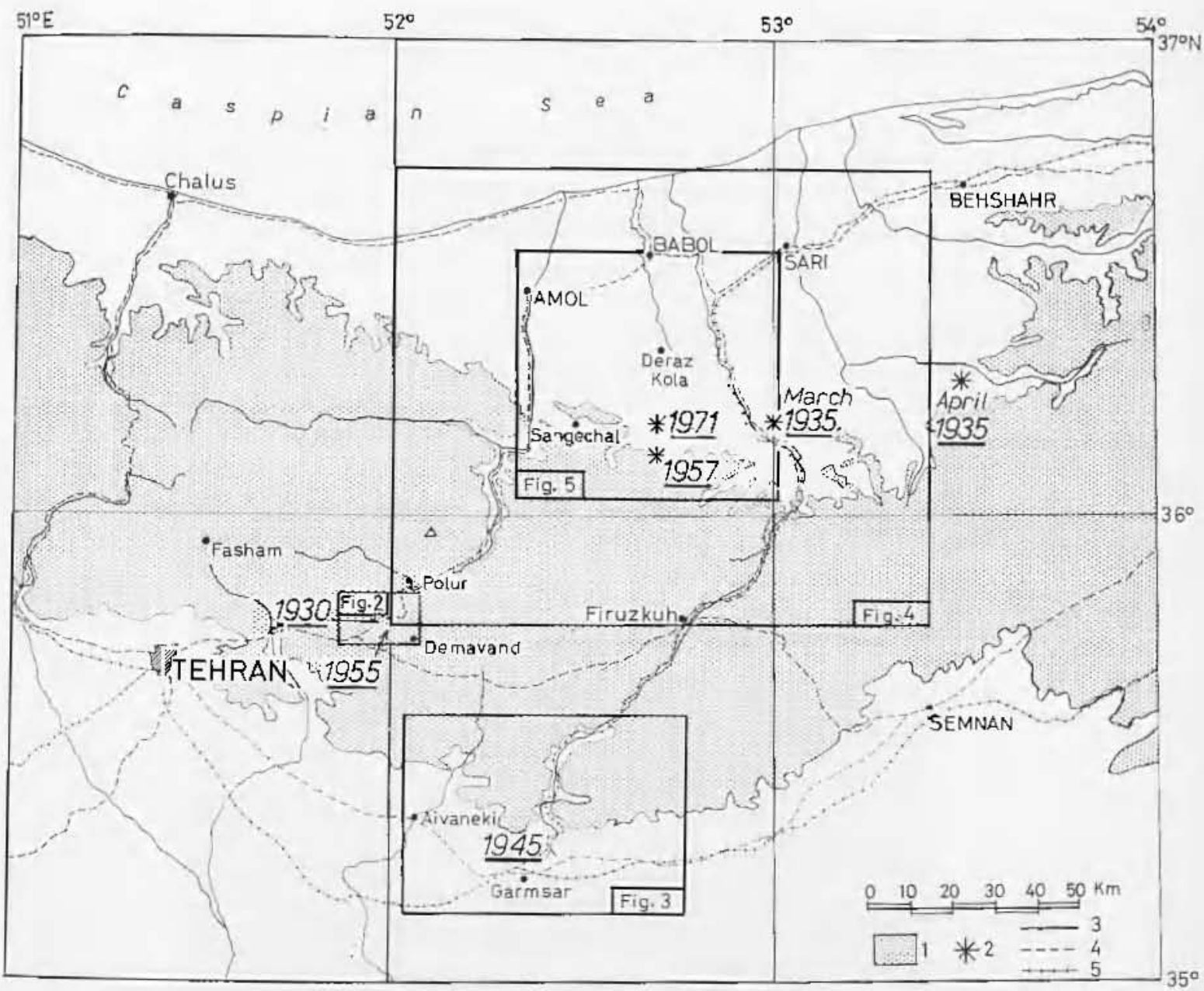

Fig. 1. - Location of 20tl C. Destructive Earthquakes in the central Albor\% - L. Regions ahove 1500 m. - 2. Instrumental epicentre. 3. Principal river. -4 . Major road. -5 . Railroad. Inserts refer to muls given in the text.

3. - JESTRECTTE EARTIQtAKLS

\section{1. - Ah-Mobanakibad Earthquake, 1930}

The earthquake occurvel on 22 nd October, 1930 at. $1.5^{113} 3^{\mathrm{m}} 12^{\text {* }}$ (r.YTT. The instrumental epicentre was deternined by ISS at $35.8^{\circ} \mathrm{N}, 52.1^{\circ}$ 
and the magnitude estimated to be above 5 (Table 1). A few villages in the Al-Ali ralley (Fig. 2 and $\mathrm{Pl}$. I) were partly destroyed: in $\mathrm{Al}$, 28 houses collapsesl and one person was killed; in Sarpurak most louses collapserl and two persons were killed, and in Mobarakabad (PI. II) a few louses collapsed and many others were severely damiged. Furtler away from the epicentre, the walls of some houses in Tamavand and Dasht-e Maanr were fissured; and in Tehran, some qunats were damaged. (iround fractures, probably of landslike origin, were reportex in the mountains north-east of Iobalakabad. Some further clammge was caused to the villages mentioned above by 1 wo aftershocks which occurred nt about 5 minutes interval on ith October, 1930, and which were felt in Tehran, Firuzkul, Tíshan and Tantaz.

Despite its low magnitude and the relatively small amount of damage enused, the eartloquale is important becuse of its proximity to Teluran and its location on the MLuslin-Fasham fault zone, a branch of which, the Nortl Teluran liault, passes througl the nortliem suburbs of the cipitul (23).

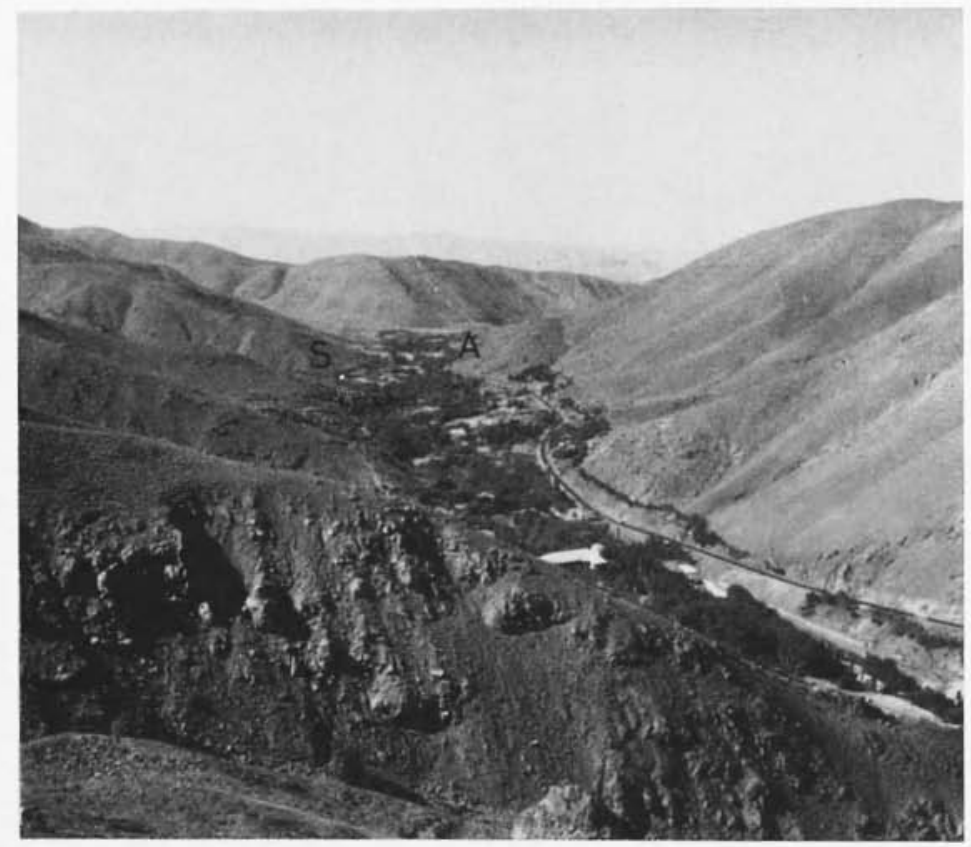

Pl, I - AB-AI.I Vatcer - $-S=$ Sarpurak; $\Lambda=\Lambda$. The large building with the white roof is the Ab-Ali masino. Looking south (see Fig. 2). 


\section{2. - Albor Enthuakes, Mare? and April 1935}

Very little is known of the two enthquakes which oceured in the Alborz mountains east of the Talar lind and eansed destruction in the Shalli and Sari alministrative distriets. The first slock which took place on the jth Marh J935 at $10 \mathrm{~m} 26 \mathrm{~m} 37 \mathrm{~s}$ GMT was located at $36.2 \circ \mathrm{N} 53.0 \mathrm{D}$ and had a maguitule of less than 6 (Table 1). The Persinn press and the Britisl Embassy in Tehran stated that 27 villages were aflected and that over 60 people lost their lives. The second

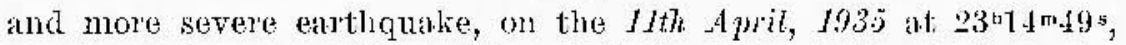
was located at $36.3^{\circ} \mathrm{N}, 53.5^{\mathrm{g}} \mathrm{E}$ and had a magnitude of about $6^{3 / 4}$ (Table 1). About 500 people wore killed in this earthouale, many mountain villuges were destroyed and buildings were damaged in Sari and Bandar Shal. The railway line east of Sari was also slightly damaged and a large rockfall was rejorted at the confluenee of the

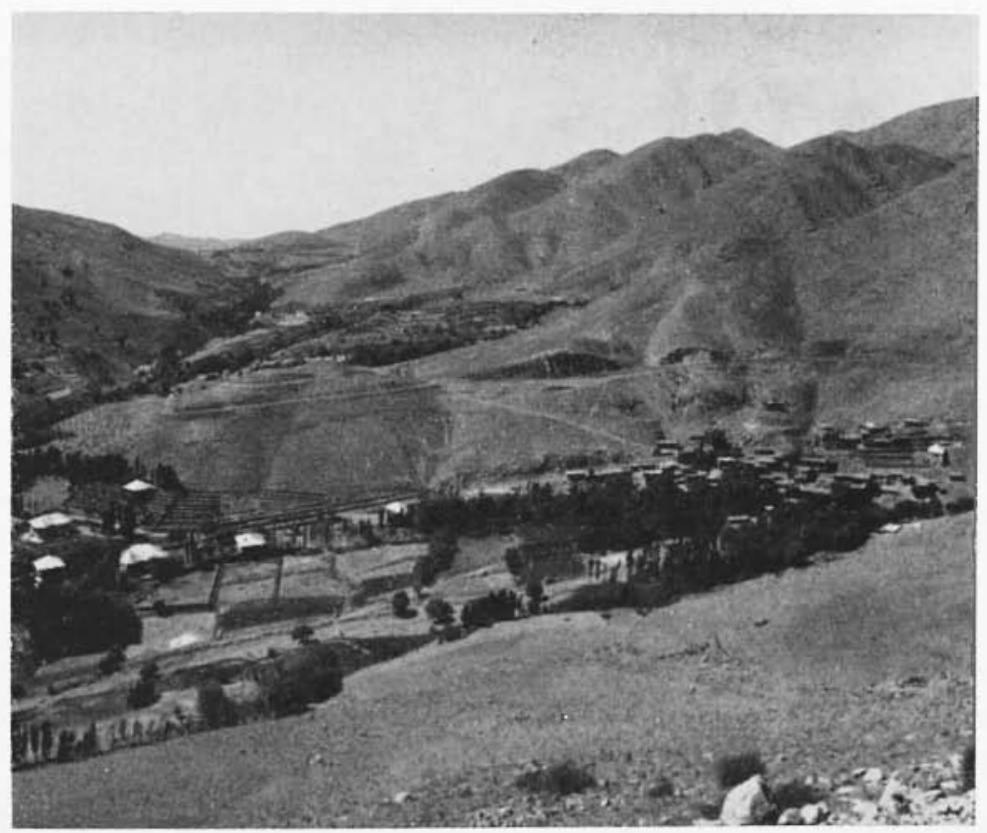

PI. Il - MonarakabaD - The village of Molmaralsalaral is at the heat of the Ab-Ali valley which crosses the pieture from left to right. The sulssiliary valley in the left background marks the trace of the Musha-Fasham fanlt zone. Looking west (see Fig. 2). 


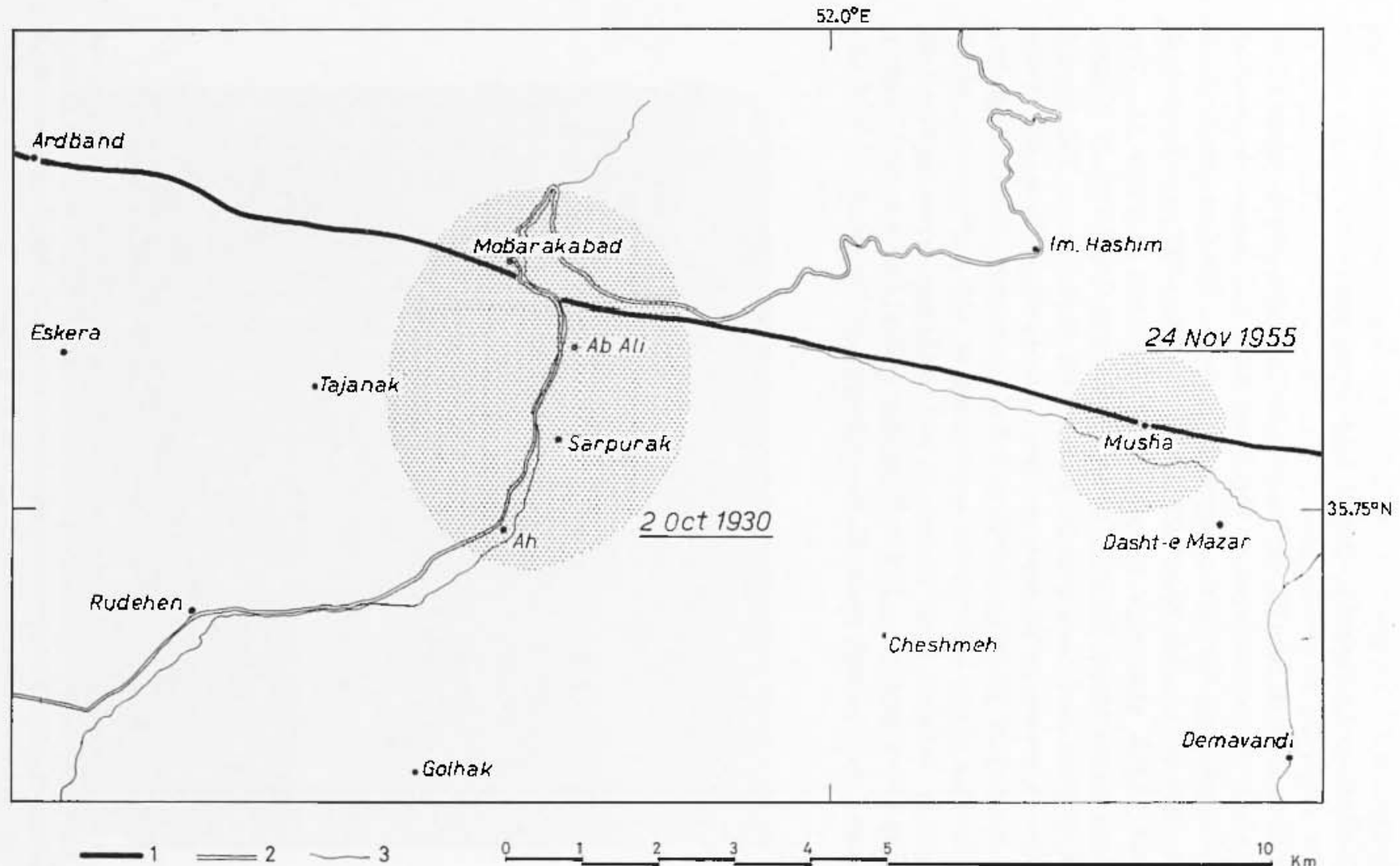

Fig. 2. - Epiecntral Regions of the Ah-Moharakahad 1930 and Musha 1955 Sarthquakes. - 1. Jusha-Fasham fault zone. -2 . Teliran-Amol road. -3 . River. Shaded areas indieate approximate limits of damage. 


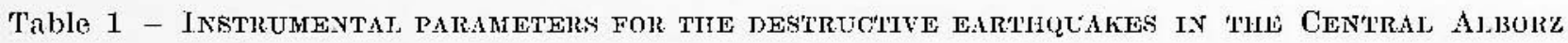

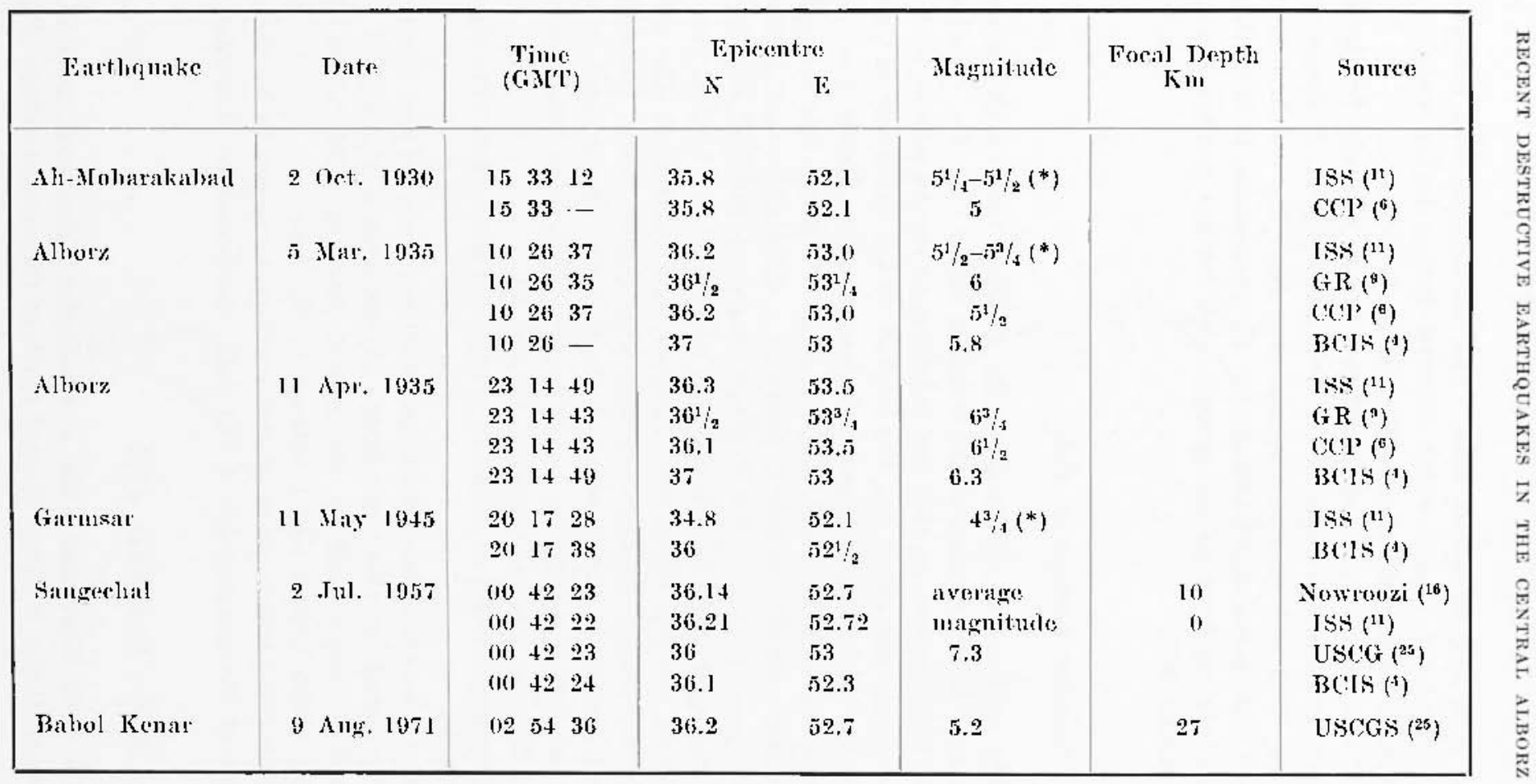

For soure abbreviations see Ruferenees.

(*) After Nabavi (1972). 


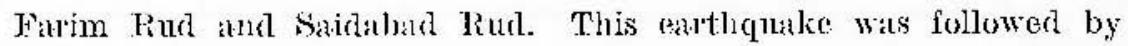
many aftershocks, one of which oceurest doring the $3 \mathrm{r}$ week in $\mathrm{April}$ and atused further damage to the buthlings in Silri.

At least one of the 1935 earthenties was strongly fell in Babol Komar, the epicuntal region of the 1971 earthouace. Tt would appear that the 1935 and 195 ] eartiquake concerned the northern foothills of the Allory below about $1500 \mathrm{~m}$ (Fig. 1), whereas the 195i dartiquake wats mainly confined to lle mountainous regions further south (see also section 3.5 ).

\section{3. - Garmsar Earthquake, 1945}

The earthquake octuried on the 11 Iny $19+5$ in the aftemom and caused lieayy damage in the cammar region (Fig. 3). The instrumental fata for Inn on that day indicates an enthouke at $20{ }^{n} 17^{\mathrm{m}} 28 \mathrm{~s}$ and of magnitude about $4^{3 / 4}$, but located $50 \mathrm{~km}$ soutliwest of Gammar (Table 1). As the data is grencrally poor for the Mitclle Fast during the 2nd World War yous, it is not known whether this epicentre is very inaceunte or whether it refers to a different event. From the Persian press we know that Barameh, Gamsar, Bonlidh and Qeshlagr were damaged (Fig. 3). In Gumsar neary all the houses were destroyed, in Qeslulacg 60 louses collapsexl, and in Bonkul the ruilway station was damaged and two persons were llorown flown. Nliogetler, the reports state that a total of about 2,000 houses were severely damaged, but they vary as to the number of porsons killed (between 8 and 20 ) and injured (between 17 and 80 ).

Ground fractures of unknown origin, and landslikles, were reported at Bonkul.

The main event was folt as three distinctive slocks and continuous shaking lasted for about one hour. Aftershocks continued for about one week. Approximately one montlı later on 19th June 1945, another slrock aused slight damage in Gamsar.

The epicentral location of this earlicpuae seems to be the same as that of the earthquate of 743 A.T. mentioned ly Ambraseys ( ${ }^{3}$.

\section{4. - Husha Earthquale, 195j}

On 24th Xovember 195\%) a small shock damaged most of the houses in Mushar, a village locuted north of Damavand village (Fig. 2). 


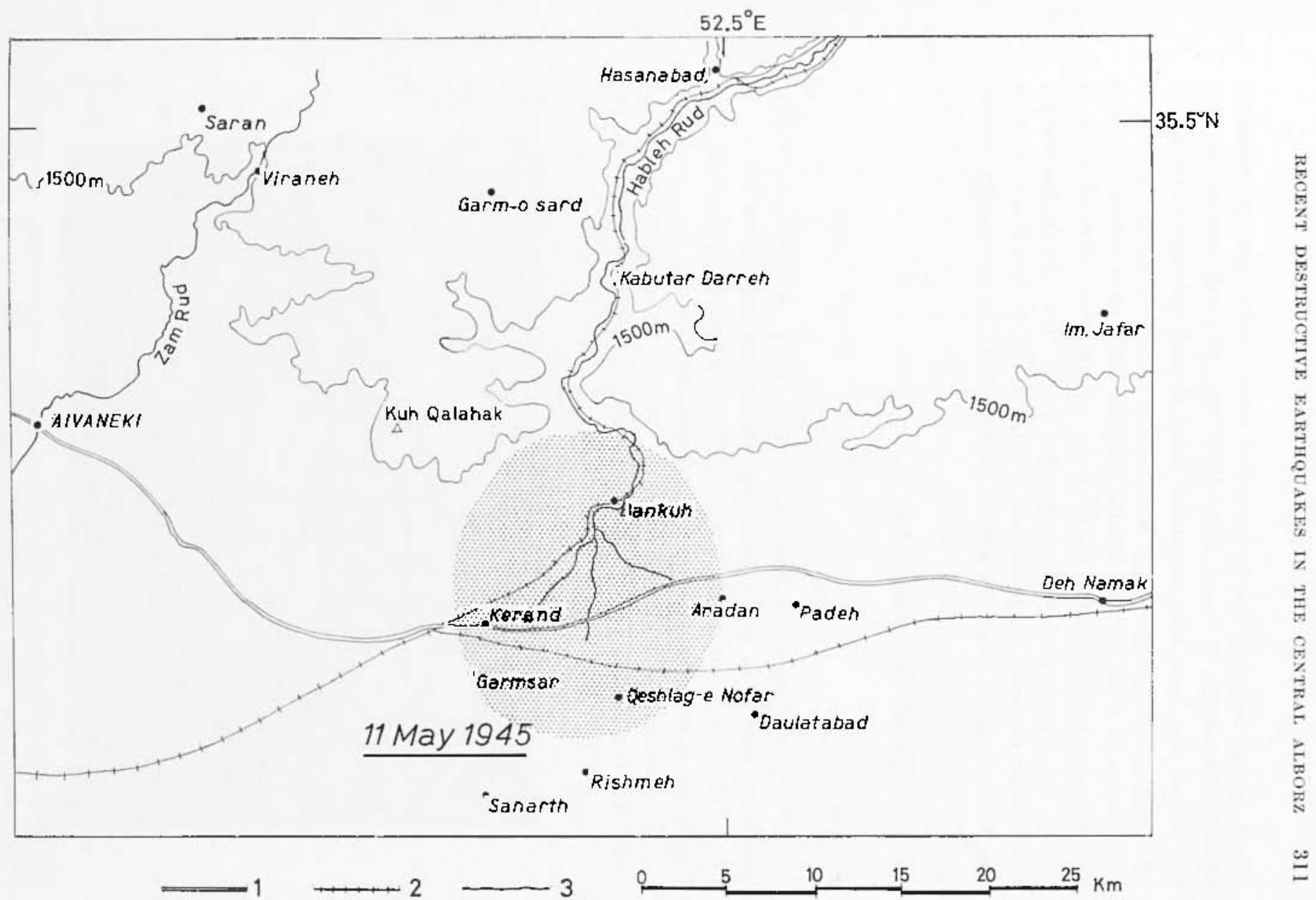

Fig. 3. - Epiecntral region of the Garmsar 1945 Earhquake. - 1. Tehran-Semun roat. - 2. Railroad. 3. Primeipal river. Shaded atea inticates approximate limit of damage, 
There is no instrumontal anta for this event which was presumably in the magnitule o range. In logt 1la villagers comfirmed that there bat not been any castaltios even thougl me house collapsed nurl mosi of the ofler's were fissmed.

Musla is built on the Muslat-Fusham fault zone which, west of the village, can be seen to truncalo Quateruary alluvial temences (Pl, JIJ). T'lis earthquake, together with the All-Mobarakabad

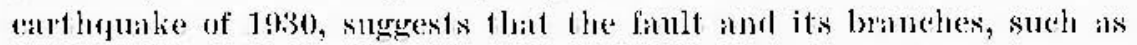
1he North Teliran Fault (2:3), should be cousirleresl as seimmically active.

\section{5. - Nangechal Eorhunale, 19jz}

\section{(ienrial}

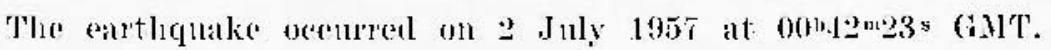
The most recent of the various ejocentral determinations (Table 1)

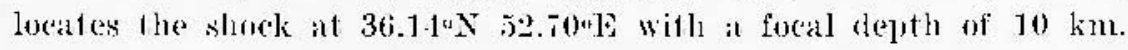
The average magnitule from several stations was 7.3 .

The epicentral rexion eovered an area of the Alborz mountains nortl of the metian clrainage divide and approximately containerl,

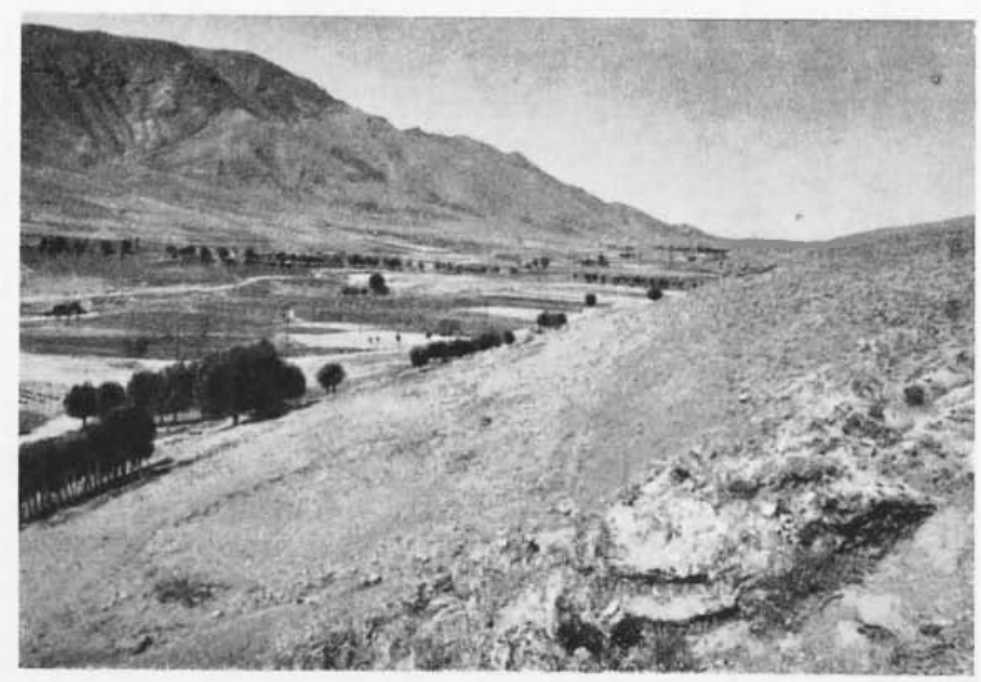

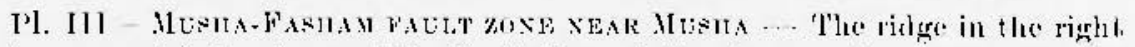
forenground is the traece of llec fault thoongh Quaternary fau or terrace material ecrentent by travertine. Looking west from Iluslat. 
between the Haraz Rod and Talar Rubl Valleys (Figr. 4). Even under normal circumstances, parts of this region are of extremely diflicull arcess, and after the earthquake the situation was agravater by numerous rockfalls which blocked all the main actess routes. In
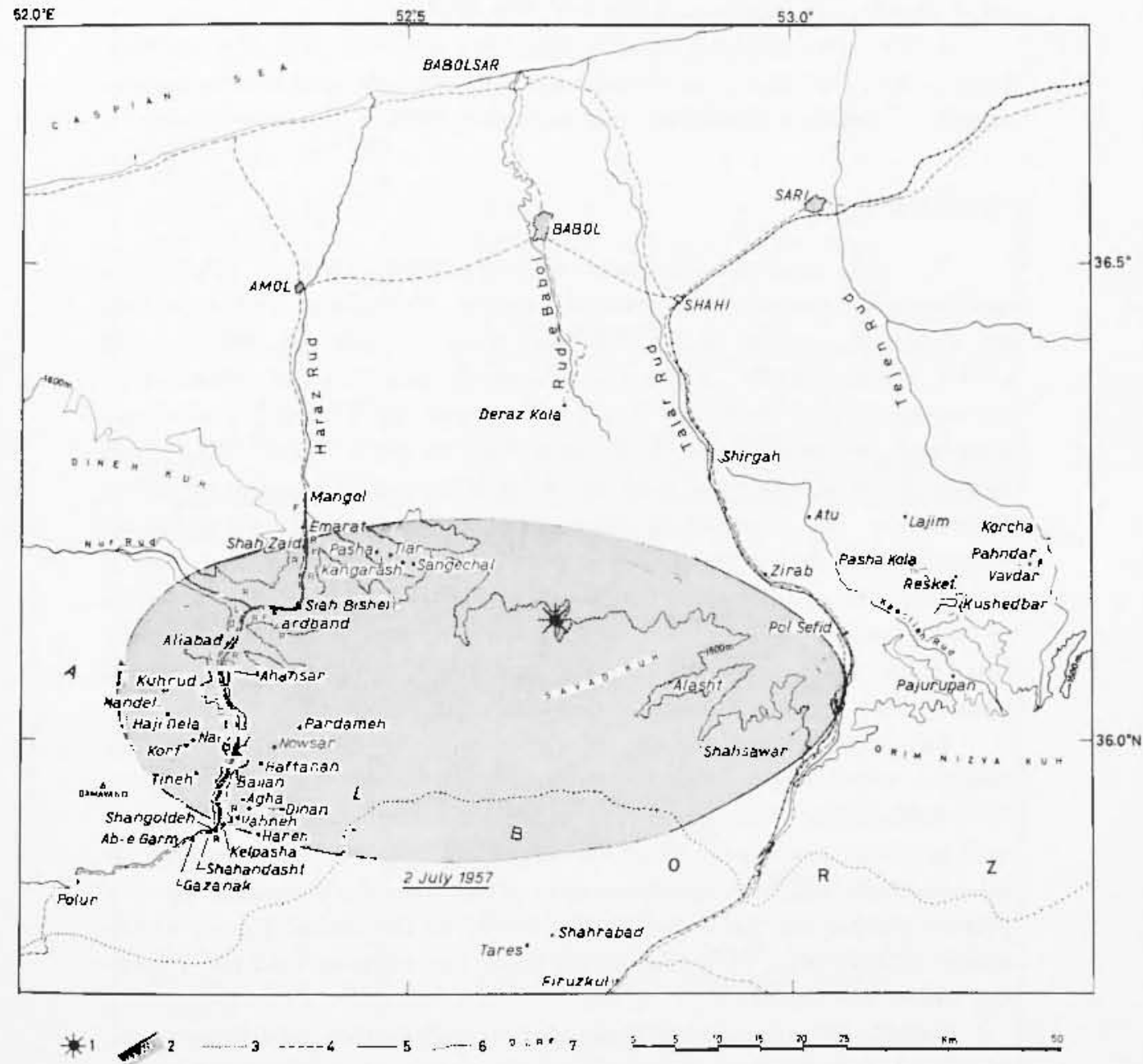

Fig. 4. - Epicentral Reginn of the Sangechal 1957 Earthquake. - 1. Instrumental epicentre. - 2. Approximate linits of the reniom of total destruc. tian. - 3. If dian Allowz drainatge divide. - 4. Major roat. - 5. Railroat. d. Principal river. -7 . J) $=$ damaged brigge or 1 momel: $\mathrm{J}$ - lamslside; $R=$ roctifall; $F=$ trromel fracture. Only villages ant lowns for which materescismic data is available are shown on the map. 
consequence, the macroseismic data is often incomplete and, for some regions, lacking entirely.

The total number of people killed was varionsly estimated at $480\left(^{10}\right)$, over 1000 (Persian press) and more than $1200(19,20,26)$. The information collected lere for 50 towns and villages shows that the total number of fatalities exceeded 970 (Table 2).

Relief was organised by the Red Lion and Sun and the military forces, ant coortinated in Teluan for the southern part of the region, ant in Babol ant shahi for the northern part.

\section{Epieentral region}

The only published account of the eartiquake (10,20) places the macroseismic epicentre near the villige of $A b-e$ Garm and considers the epicentral region to be "circular, with a radius of $100 \mathrm{~km}$ and centre approximately at the Damavand Folacno". The information on whicl this account was based is a rejort by Vrolyk ( $\left.{ }^{26}\right)$ who was impressed by the dimage to the new hotel in $A b-e$ Garm. The hotel lowever was an untypical ase (see further on) and the region of severe destruction was located further north and east of $\mathrm{Ab}-\mathrm{e}$ Garm. IIngiwar and Naito (10), without actually entering the area, estimated correctly that the highest intensities occurred about $60 \mathrm{~km}$ south of Babol and $30 \mathrm{~km}$ west of Zirab. As already mentioned, the destruction of the main access roads made it difficult to enter the epicential region after the eurtiquake.

The umpublished reprorts of C. Savage (21) constitute the only reliable information on the situation in the epicentral region after the earthquake. Savage visited the Hasaz Rud and Kaselian Rud valleys about one month after the event and rejorted in detail on his observations. A few special points were also investigated by the present anthor on the oecusion of a study of the Babol Kenar earthquake of $1971{ }^{(24)}$. It is mainly on these two sotures that the following notes are based.

Dosprite the unevenness of population distribution, and the pancity of reliable information, the limits of the region of maximum destruction ean be established with reasonable confidence. Maximum testinction occured between the Haraz Rut valley in the west, the Talar Rud valley in the east, the Caspian foothills in tle north (above $1500 \mathrm{~m}$ ) and the median Alborz trainage divide in the south (Fig. 1). The macroseismic information is summarized in Table 2. 


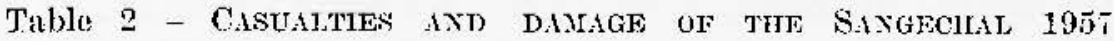
EAR'THQQUANE

\begin{tabular}{|c|c|c|}
\hline Village & Killed & R.E $\mathrm{NARKS}$ \\
\hline Ab-c Garm & 0 & Ilotel nuler construetion partly destroyed. \\
\hline Agrlıa & 24 & \\
\hline Aliansar & 3 & \\
\hline Alasht & & Severe damage. \\
\hline Aliahar & 0 & One honse onls: bally damagerl. \\
\hline Amol & 0 & Tolrace warehouse daniaged. \\
\hline Atiu & & $\begin{array}{l}\text { Worst damage of Kasclian Valley. Some } \\
\text { houses collipset. Casualties? }\end{array}$ \\
\hline I3abol & 0 & $\begin{array}{l}\text { Danage to water tower and } 100 \text { yoar old } \\
\text { tree. }\end{array}$ \\
\hline Baijan & 10 & $\begin{array}{l}\text { Yearly all houses (well hiilt) collapsed, } \\
\text { Bridge tamageil, o injured. }\end{array}$ \\
\hline Chirgar & & Jocution unkuown. Badily danaged? \\
\hline Deraz Kola & 0 & No dlanage. Weaker than 1935 carthı \\
\hline Dinan & 63 & I3uried by rockfalls. \\
\hline Emarat & 0 & $\begin{array}{l}\text { All ten louses (badly built) damaged. } \\
1 \text { injured. }\end{array}$ \\
\hline Gazanali & 0 & \\
\hline Jlaftavau & 3 & 15 houses destroyexl. \\
\hline Ilajiılcla & 56 & \\
\hline JI:reth & 6 & \\
\hline Kangarish & 45 & \\
\hline Kelpaslıa & 15 & \\
\hline Khuslextlsar & 0) & slight 丸anage. \\
\hline Korcha & 0 & II axilly any dannage. \\
\hline Korf & 12 & \\
\hline Kuh Rut & 12 & $\begin{array}{l}5 \text { or } 6 \text { houses desfoyed hint other part of } \\
\text { village not collapsed. }\end{array}$ \\
\hline Jajịm & 0 & No damage to honges or llthe Al) tower. \\
\hline Mangrol & 0 & l3ady built yet very little damage. \\
\hline Nauslel & $6 \tilde{6}$ & \\
\hline Nowsar & 13 & \\
\hline $\mathrm{Nal}$ & + & \\
\hline Pajurupan & 0 & Bully daminged, 6 honses collapsed. \\
\hline $\begin{array}{l}\text { Palintar } \\
\text { Pardameh }\end{array}$ & 84 & Casnalties? \\
\hline l'asha & & Casnalties? Barlly damaged. \\
\hline Paslia Kola & 0 & Jlouses well built, some partial collapsse. \\
\hline Pol sefirl & $\{60)$ & Quite hatly damiged. \\
\hline
\end{tabular}




\begin{tabular}{|c|c|c|}
\hline Villatre & Killerd & $\mathrm{RF} \mathrm{N} A \mathrm{RK}$ S \\
\hline P'olur & $(30)$ & Great danage? \\
\hline Resket: & & Casnalties? Batly damaged? \\
\hline Sangechal & 180 & $\begin{array}{l}\text { All houses destroyed. Jandslides. Ground } \\
\text { fractures? }\end{array}$ \\
\hline Sari & 0 & \\
\hline Shahandashi. & 13 & Immanzadeh badly damaged. \\
\hline Shahi & 0 & Only 2 buildings damagesl. \\
\hline Shalırabad & & Completely ruined. \\
\hline Shahsavar & 0 & Many buildings ruined. \\
\hline Ślıalı Zaid & (j) & $\begin{array}{l}\text { Very bad damage to well built houses. } \\
\text { Ground fractures? }\end{array}$ \\
\hline Slıangoldeh & 30 & Very bad damage nearly entirely by rockfalls. \\
\hline Slıemiran & 0 & Yo damage. \\
\hline Siahbisheh & 5 & $\begin{array}{l}\text { All } 1+\text { houses (well buill) destroyed. Animals } \\
\text { killet. }\end{array}$ \\
\hline Slitrogah & & Less damage than $\mathrm{Alu}$. \\
\hline Tares & & Completely ruined. \\
\hline Tiar & 3 & Damage less than Sangeehal. Tandsliıles. \\
\hline Tera & 28 & 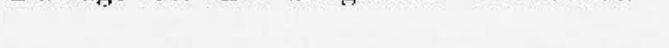 \\
\hline Vannch & 0 & $\begin{array}{l}\text { Iumaumadeh damaged but village only } \\
\text { slimlitly. }\end{array}$ \\
\hline $\begin{array}{l}\text { Vavdar } \\
\text { Zardband }\end{array}$ & 6 & $\begin{array}{l}\text { Casualties? Ground fractures? } \\
\text { All } 20 \text { houses (badly built) destroyed. Mach } \\
\text { damage by roekfalls. }\end{array}$ \\
\hline Zirab & $(200)$ & \\
\hline Total & $9 \pi 0$ & \\
\hline
\end{tabular}

Figures shown in ( ) inclieate that numbers refer to uniclentified nearlby villages.

In the Haraz Rud Valley, the following villages were totally destroyed and suffered a large number of casualties: Agha, Baijan, Dinan, Kangarash, Haji DeLa, Kelpaslıa (?), Kort, Nandel, Fowsar Pardameh, Sangeehal, Shah Zaid, Shangoldeh, Siah Bishoh, Tineh (?) and Zardband. In Baijan, for example, where the houses were relatively well built, all the buildings inchuling the police post, flour mill and public baths collapsed, killing 10 people and injuring 6 . An $80 \mathrm{~m}$ long bridge north of the hamlet was damaged. Some of the villages, particularly Shangoldeh, Dinan and Zardband were at least as much damaged by rockfalls as by the shaking. Next in the degree of destunetion was a grouly of villages which were also very severely damaged 
but which generally lad only a few fatal casualties: Ahansar, Nliabal, Haftanan, Harel, Fuhrul, Fal, Pasha, Shahandaslit, Tiar and Vamel. In Kinhrud, for example, where 5 or 6 houses collapsed, killing 12 people, part of the vilage was still standing after the earthquake. The severe destruction in the Haraz Rud Valley decreased appreciably near Emarat and Mangol in the north, and Polur and Ab-e ciarm in the south. In Ab-e Garm, the reinforces conerete lotel described by Vrolyk ( $\left.{ }^{26}\right)$ as completely destroyed, "... had never been completed and many of the slabs were still resting on their slut tering . . one land to wonder if it would have stood up even if it lad been completed... the main trouble seems to have been the too heavy roof/floor slabs on too slender columns" (21).

A very great number of lauklslides and rockfalls were saused by the enrthquake, both in the Haraz laud and in its tributary valleys. Many villages were damiget or destroyed by rockfalls and the TeluanAmol road was blocked at several points (*). The largest rockfall occurred on the east bank of the Fara\%, about $3 \mathrm{~km}$ soutl of the Nur Valley confluence. About $10,000 \mathrm{~mm}^{3}$ of rock fell from a $500 \mathrm{~m}$ eliff, blocking the valley, forming a tlam about $20 \mathrm{~m}$ high ant ereating a reservoir about $1 \mathrm{~km}$ long and $100 \mathrm{~m}$ wide.

The Talar Rud Valley at the enstern limit of the epicentral region is less well tocmmented than the IIaraz Rud. The Persian press reported more than 200 people killed in Zirab, and 60 in Pol-e Sefid, but in both cases there are indicutions that these casualties occured in fact in the monntain settlements west of these two villages. Alasht and Shahsawar were seriously damaged bnt seemingly witlout fatal castunlties.

Further east in the Kaselinn Rud and Tejen Rud Valleys some villages such as $\Lambda$ tu, Pajurupan, Pasha Kola and Resket were partially dinmaged ant a few houses collapsed in each. Slight damage was observed in Kinushedbar, Pahmlar and Vivilar, but Lajim and Koreha were harilly damaged at all.

In the north the destruction did not extent into the Caspian foothills below about $1500 \mathrm{~m}$. Shirgah and the Babol Kenar villages around Deraz Kola were maffected $\left(^{* *}\right)$. Some isolated cases of light tlamage did however oceur in the towns of the plain: the tobaceo

(*) See also Figs. 8 and $\theta$ in Fookes and Knill (1969).

(**) The Sangechal earthquake was felt here less strongly than the 1935 earthquates. 
warehouses in Slahi, Sari (?) ant Anol (?), and the water tower in Babol were slightily damagetl.

In the south, Shalmabad and Tares nedr Firughul were damaged but without reported asmalties. None of the villages on the PolurTehran road seemed to be seriously aflected. The slock was strongly felt, in Tehman (8) and in shemiran but dit not produce any visible damage to buillings.

\section{The question of foulting}

Rothe $(19,20)$ states that a fault-break was observel to cross the half-destroyed hotel at Ab-e Garm, his information being based on the following remark by Vrolyk ( $\left.{ }^{26}\right)$ : "J' 'ajoute (ear' j'ai un prelle mignon, celui d'être radiesthésiste) que le pendule nu'a prermis de reconnâture sur place une faille...". In fact, photograplis of the hotel taken by

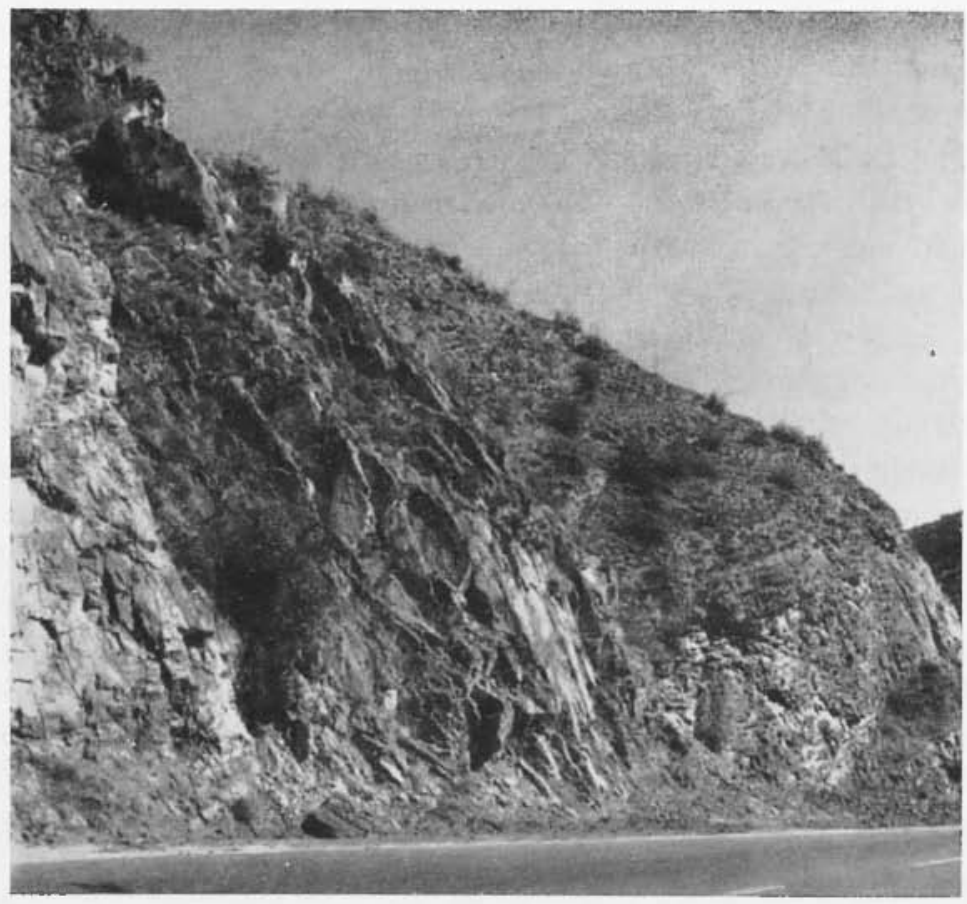

Pl. IV - AMIR FALL zONw - The fault zone in the foreground is a stec south dipuing reverse fanlt in thin-bedted limestone. Jeft-bank of the IIaraz Rud. Looking south-cast. 
Savage suggest that the frature in question was due to slumping or incipient sliding, and a recent geological map of the region contirms the absence of a fault in the vicinity of $\Delta b-e$ Gam (').

Some fault movement seems however to lave taken place along the Amir Fault zone which is locatel along the Amir Rud, a small eastern tributary which joints the Haraz at Mangol. 'T'le geologiea] fanlt is well linown here even though not mappet in detail: it is a steep south tlipping reverse fault with a shear zone about $25 \mathrm{~m}$ wide there where it crosses the Iaraz valley (Pl. IV). In 1957 after the earthquake it was notel that "a small fault was seen beside the road with fresh artas" ${ }^{(21)}$. There were also unconfirmet reports of large grouml fissures, several kilometers long, in the mountains north of Singechal, one of the most severely damaged villages of the earthquake (1?. V). Sangechal is situated on a steep hill showing numerous

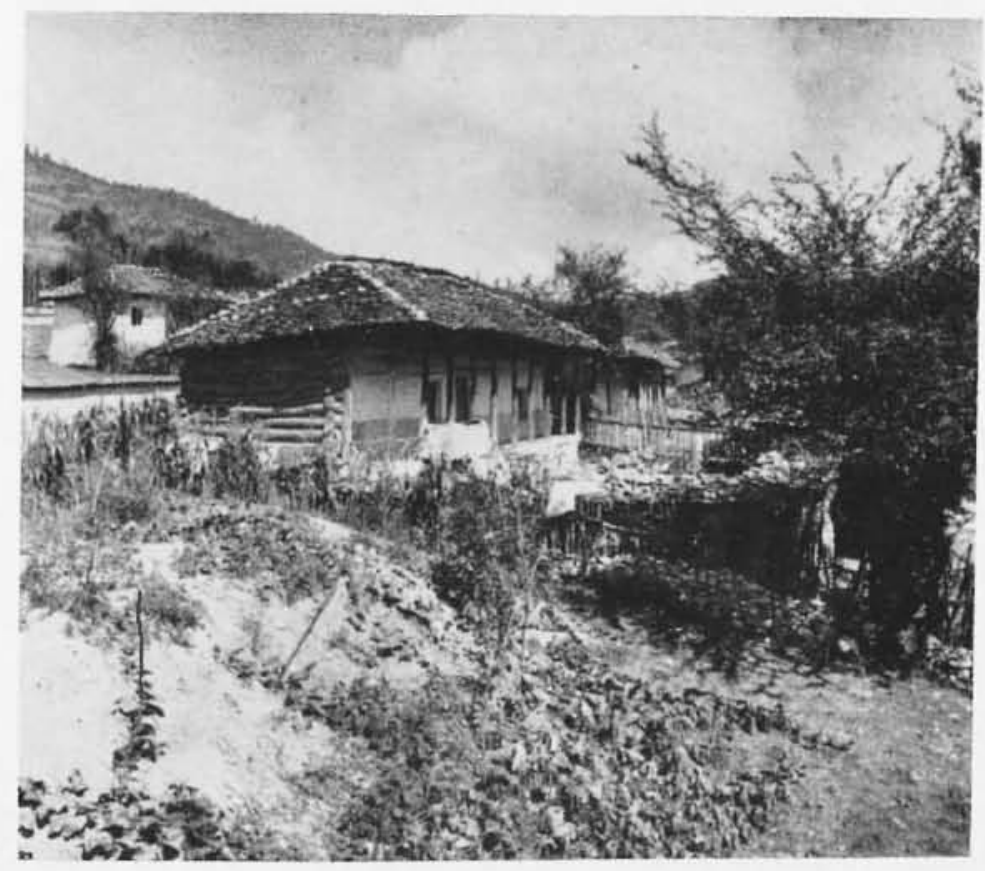

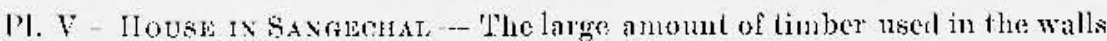
is an innovation after the 1957 earthquake. The rouf is (as in 1957?) of wood shingle. The mound ant gitutcu in the left foreground mark the foundations of a house which was testroyed in the 1957 eartheluake. 180 people out of a population of about 4000 were lilled by the carthquale in sangeehal. 
landslisle stal']s (Pl. VI); these laudslides are ocedsionally reactived, as after the Babol Fenar eartlquake in 197, and this probably explains the ground fissures olsorverd in 1957. Both the liaraz and its tributary vallegs ares very prone to landslisles and rockfalls, and these ctull be triggered-ofl by eathquakes or other natulal causes.



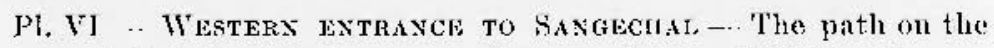
right is locaterl along one of many uld limislisle sturps.

\section{3.ti. - Babol-Tenar Earhquake, Igr/}

The Babol-Kenat exthquake of magnitude 5.2 oceurred on 9th August 1971 at $02^{n} 54^{\mathrm{m}} 36^{\mathrm{s}} .7$ GMIT; the instrumental epiechtre was

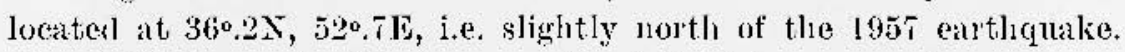
About 900 houses in 42 villages sufioresl light damage and one prexson diel and 39 were injured. The epicential region was situated along the northern foothillis of the Alborz. (Fig. 5), with the severest alamage around Desaz Kola. Damage did not extend into the mountains above about $1500 \mathrm{~m}$ in the region of the 1957 eartlugualke.

Details of the worst hit region lave been previously reported (24). Some furtler information obtained recently on the villages in the 
southwest and east enables a clearer pieture to be drath of the areat over which the shock causerl damige (Fig. 5).

\section{4. - POPUTATIOX DISTRHBTTIOX AXV EPTCETKAL REGHON}

The amount of damage and the number of casualties resulting from an earthquake is, to a large extent, dependant on the population

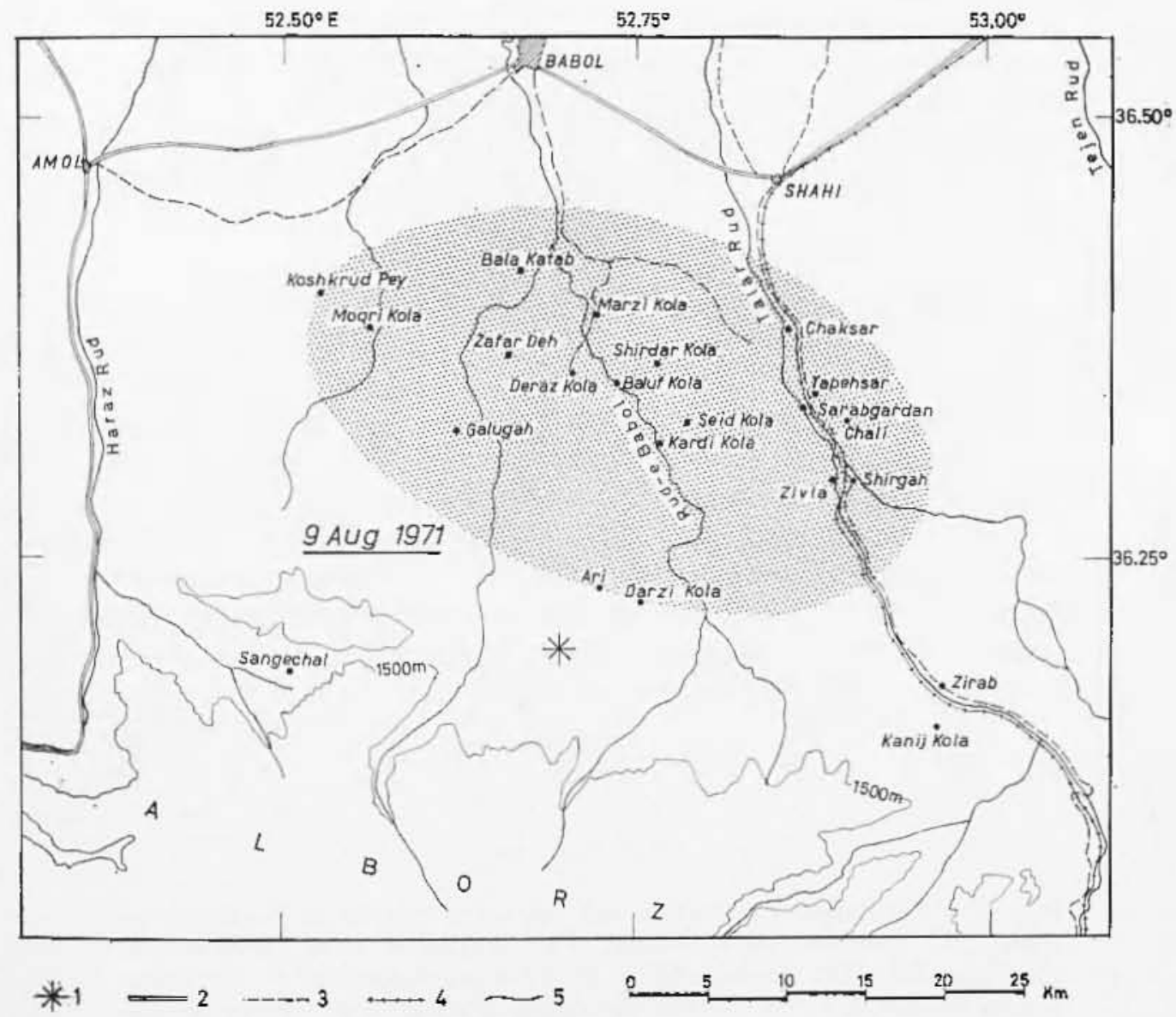

Fig. 5. - Fpicentral Regrion of the Balol-Kenar 1971 Eartluquake. - I. Instrumental epicentre. - 2. Jajor road. - 3. Other road. - 4. Railroad. 5. Principal river. Only villages and towns for which matroseismic data is available are shown on the mats. Shated area inclieates approximate extent of damage. 


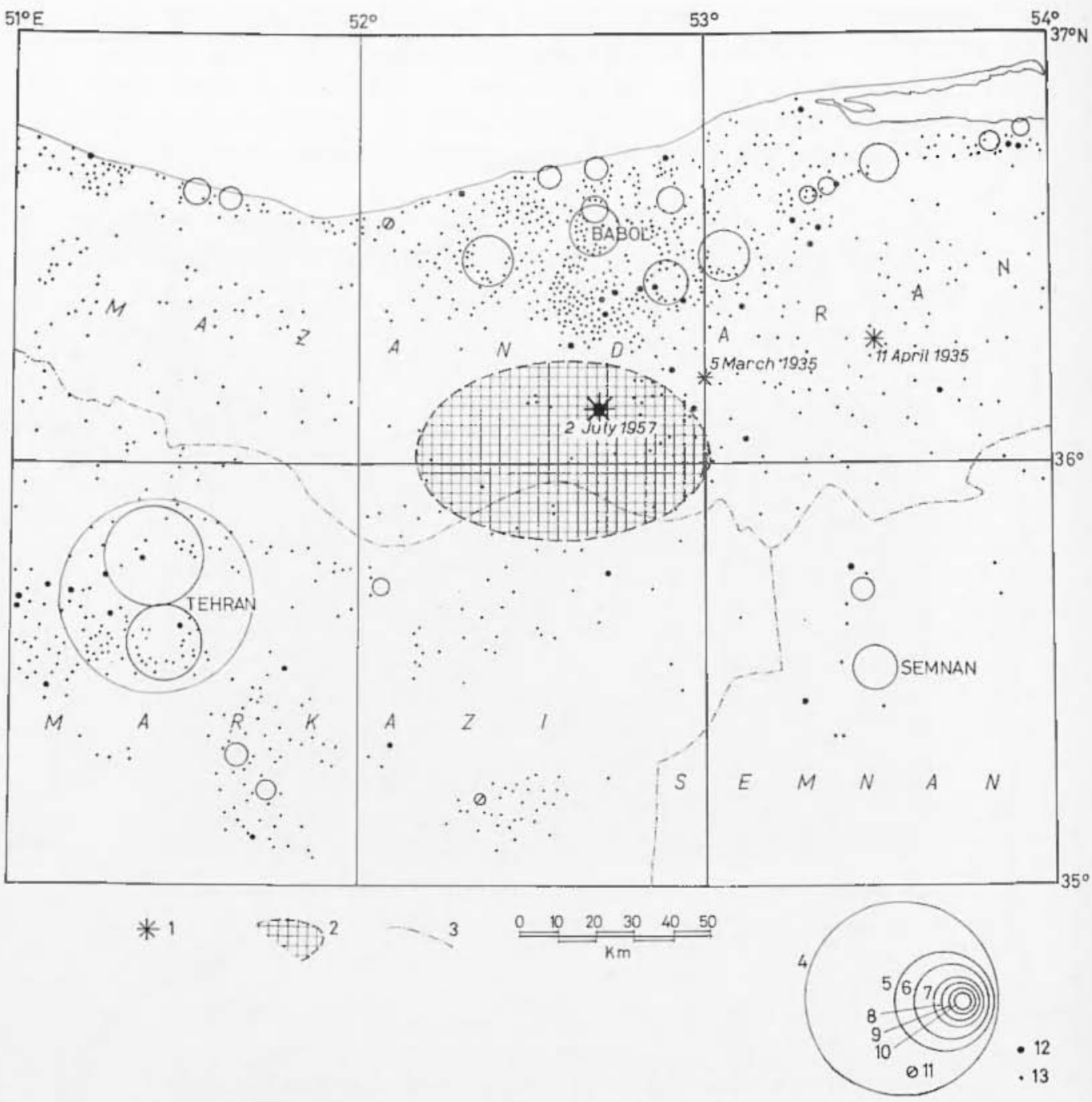

Fig. 6. - P'opulation distribution and epicentral regions in Nortlt-central Iran. - 1. Instrumental epicentres. - 2. Region of total destruction of the Sangechal 1957 earthquale. .. 3. l'rovince houndary. - 4. lirban population 500,000. - 5. lirban population 250,000. - 6. Urban population $100,000 .-7$. Lrban population 50,000 . - 8. Urban population 25,000, - 9. Uriban population 15,000 . - 10. Urban population 5,000 . 11. Urban population less than 5,000. - 12. Rural population 2,000 to 5,000. - 13. Rur'al population 1,000. After the 1966 population census pulblished by the Statistical Centre of lran. 
density in the epicentral region. Fig. 6 slows the gopulation distribution in North-central Iran. The 1957 epicentral region covers one of the least populatel areas of this part of the country; had the earthquake occurred further north near Babol or furtler soutli-west near Tehran, a catastrophe of much greater proportions may have resulted. Similarly, the exthquakes of March and $A$ pril 1935, even though less precisely located, also occurred in regions of low population density. Research into earthquakes prior to 1900 does however show that this had not always been the case, as both Telurn (Sliahr Rey) and the Caspinu constal towns lave been destroyed a number of times in thle past ${ }^{2,3}$ ). It is one of the reasons why the stuly of smaller events located near the population centres, suc $]_{1}$ as $\mathrm{Al}_{1-\mathrm{A}}$ Iobarakabad 1930 , Wusha 1955, and Babol-Kenar 1971, are of vilal importance to the assessment of the seismic latard of the region.

\section{ACKNOWLEDGEHEN'S}

The field work rejorted here was undertaken as part of a joint project between the Geological Survey of Iran ant the Engineering Seismology section, Imperial College, Tondon, the latter being supported for this work by a grant from the National Envirommental Research Council, Toudon. I am grateful to Sir Alexander Gibb and Partners, London, for acess to C. T. W. Savage's reports. Part of the field investigation was carried out with $\mathrm{HT}$. Iranmanesh of the Geological Survey of Tran and $A$. MLhajer-Ashjai presently at Imperial College, ant it is only witl their help and cooperation that this stuly became possible.

\section{RFFERJNCES}

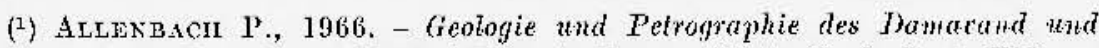
seiner Cmgebmg (Zentral-Elburz), Iran. "Mitt. Geol. Inst. Liılgen. Tech. Hochsch. Univ. Zürieh"", N.F., 63, py. 144.

(2) Ambrasers N. N., 1968. - Early earthquakes in North-Central Iran. "Bull. Seism. Soc. Am.", 58 (2), $485-496$.

(3) Ambraseys N. N., 1973. - Ifistorical seismicity of Norlt-centrat Iran, in Miaterials for the Study of Seismotectonies of Iran: Forth-eentral Irair. "Geological Survey of Irau", Report No. 29 (fortheoming). 
(4) B.C.L.S. Burean Central International de Seismologie, Strasbourg. Franee.

(5) Bozorfisia II., ]969. - Statintics on Earthquakes in Iran. "National Iranian Oil Company", Geological Rejort 253, mp. 23.

$\left({ }^{6}\right)$ CCP - Athas of Earhquates in the CSSR. "Acad. Sci. TSSR", 1962 (in russiau).

(7) Fookes I'. G. ant Kxm. J. I., 1969. - The application of engineering geology in the regional dexelopment of nowhern and central Iram. "ling. Geol.", 3, 81-1201).

$\left({ }^{8}\right)$ Gaxssud A., 1969. - The larpe eathauaties of Iran and their geologieal frome. "Eologate Genl. IIelv.", 62, 443-466.

(9) GR-Gutexbenc: B. and Ricitek C. F., J954. - Seismieily of the Earlh and Associated Phenomena. 2nd Ja. Prineeton, New Jersey. Princeton Lniveraily Press.

$\left.{ }^{10}\right)$ Ilatiwara T. antl XaITo T., 1959. - A reporl of the Japanese Hission sent to Iran for incestigating the problems related to disastrous earthquates in Irrt. Unpublishet report, January 1959, Jys. J00.

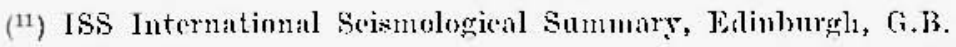

(12) Mckexze 1),, 1970 . - Plate tentonies of the Meditemanean region. "Nature", 226, 239-243.

${ }^{(13)}$ MeKexzie D., 1972. - Actice teptonies of the Mefliterancen region, "Creopliys, J.R. astr. Soc.", 30, 109-185.

(14) Mostasbos l'., 1957. - Lex grandes calastrophes en 1956-195\%. "Rov. pour l'Etule: des Calamites", 35, 52.

(15) NABAy M. S., 1972. - The Seismicily of Irom. Ml. Sc. Thesis, Cniversity of lomdon, 1972.

$\left.{ }^{16}\right)$ Nowrooz A. A., 1971. . Seismo-tectomics of the Persian Platean, Eastern Turkey, Coucasus, and Jindt Kwsh regions, "Bull. Seism. Soc. Am.", 61. $317-341$.

(17) Nowroozi A. A., 1972, - Foout Meohanism of earthuakes in Persia,

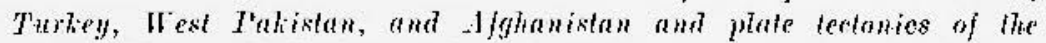
Midlle East. "Bull. Scism. Soc. Am." 62, 823-850.

(18) Rezasov I. A., 1959. - Tectonics and Seismicity of the TurkmenoThomssan Mountains. Acad. Sei. ISSSR, Inst. Plyss. Eath, pp. 243 (in russian),

(19) Rotie J.P'., J959. - Chromique seismologique. "Rev. pour l'Etude des Calamites", 36, 16-17.

$\left.{ }^{20}\right)$ Rotne I.-T., 1969. - The Seismicily of the Earth 1953-1965. Unesen, Paris.

$\left.{ }^{21}\right)$ Savage: C. D. W., 1957, - Earthguake of 2 Md July and Snfori Memoromlum. Sir A. Giblss and Partiers, London, Internal Reports B.45 (lated 20 July 1957, and B58 dated 12 August 1957. 


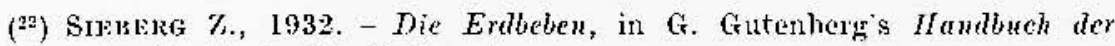
feophysik, 4, Eal. G. Borntracger.

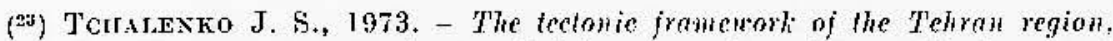
in Naterials for the Study of Seismotectonies of Iran: North-eentral Tran. "Geol. Surv. Iran", Rep. No. 29 (fortheoming).

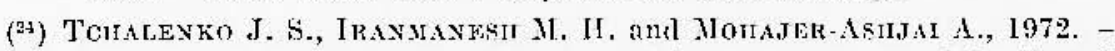
The Babol-Kenar (1971) earligunke am the seismotectonics of the Central llhorz (Tran). "Ann. di Geofisica", 25 (1), $27-36$.

(25) LSCGS - Linited States Coast and Geodetic Survey, Washington. l'relininary and suntlity determination of epiecntres.

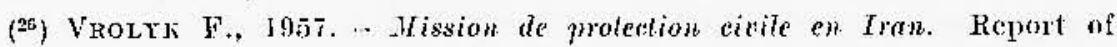
the Government of Algeria, Septemher $195 \bar{i}, 1$. 15 (in french).

(27) WiLsox A. 11., I930. - Earthquakes in Persia. "Bull. Sel. Oriental Studies", 6 (1), 103.131. 